\title{
The history of the UK's pioneer distance education university: the Open University \\ An interview with Martin Weller
}

\section{L'histoire de l'université à distance pionnière au Royaume-Uni : l'Open University - Entretien avec Martin Weller}

\section{La historia de la universidad a distancia pionera en el Reino Unido: la Open University - Entrevista con Martin Weller}

Hélène Pulker, senior lecturer in French

The Open University, Royaume-Uni

helene.pulker@open.ac.uk

Cathia Papi, professor

Université TÉLUQ, Canada

cathia.papi@teluq.ca

\begin{abstract}
In his interview, Professor Martin Weller explains the origins of the Open University, the UK's pioneer distance education university, and describes the different contexts in which the Open University has had to navigate through in the last 50 years. The interview focuses on showing how the Open University's mission (to be 'open to people, places, methods and ideas') has been at the heart of the institution's developments, and how the concept of openness has evolved throughout the changes and the challenges of the recent years.
\end{abstract}

Keywords: open education, online and distance learning, supported learning, higher education, United Kingdom 
Dans son entretien, le professeur Martin Weller parle des origines de l'Open University, l'université à distance pionnière au Royaume-Uni, et décrit l'évolution de l'Université depuis sa création, il y a 50 ans. Dans ses propos, il souligne, d'une part, l'importance du rôle qu'a joué la mission de l'Open University (être « ouverte aux gens, aux lieux, aux méthodes et aux idées ») dans les développements de l'établissement et, d'autre part, la manière dont cette notion d'ouverture a évolué au travers des changements et des défis auxquels l'Université a dû faire face au fil du temps.

Mots-clés : formation ouverte et à distance, apprentissage à distance et en ligne, accompagnement pédagogique, enseignement supérieur, Royaume-Uni

RESUMEN

En su entrevista, el profesor Martin Weller explica los orígenes de la Open University, la universidad a distancia pionera en el Reino Unido, y describe los diferentes contextos en los que la Open University ha tenido que desenvolverse en los últimos 50 años. En sus comentarios, destaca, por un lado, el importante papel que su misión (estar "abierta a las personas, a los lugares, a los métodos y a las ideas") ha desempeñado en el desarrollo de la institución y, por otro, cómo esta noción de apertura ha evolucionado a través de los cambios y de los retos a los que se ha enfrentado la universidad a lo largo del tiempo.

Palabras clave: aprendizaje abierto, formación a distancia y en línea, apoyo pedagógico, educación superior, Reino Unido

Martin Weller is the director of the Open Education Research Hub, the director of the Global OER Graduate Network (GO-GN) and the director of the Open Programme at the Open University. Weller chaired the Open University's first major online e-learning course in 1999, which attracted 12,000 students, and was the OU's first Learner Management System Director. His popular blog, edtechie.net, features his writings on various aspects of educational technology. He is the author of The Twenty-Five Years of Ed Tech (2020), The Battle for Open (2014) and The Digital Scholar (2011).

HÉLÈNE PULKER \& CATHIA PAPI: Could you talk about the origin of the Open University? When was it founded? What was the educational context at the time and the purpose of a distance university in the UK? Who was the Open University created for?

MARTIN WELLER: It was founded in 1969 by the Labour Government of the time. At the time, higher education was still largely an elite pursuit. The Open University $(\mathrm{OU})$ was designed specifically to meet the needs of people who were excluded from higher education, because they could not study full time, or attend a campus, or people who had not done well in early education, and thus did not have the entry requirements. It was sometimes referred to as the 'university of the second chance'. 
HÉLÈNE PULKER \& CATHIA PAPI: Can you describe what the Open University was like at the beginning? Who were the main stakeholders? How was distance education organised then?

MARTIN WELLER: Obviously, I wasn't around at the foundation, but I have worked with many who were. It was revolutionary at the time, and they were developing a new system. There was a specific intention to use new technology and pedagogic expertise (see the founding documents of our Institute of Educational Technology at http://blog.edtechie.net/identity/iet-the-ou-and-identity/). They designed a system that was intended to be studied part-time and at a distance, so with little face-to-face contact, asynchronous activity and well-written course materials that could be studied independently, but with a support structure of parttime tutors. The OU mission statement, "open to people, places, methods and ideas", encapsulates much of the practice in the founding years. You can see more about the foundation here: https://50.open.ac.uk/.

HÉLĖNE PULKER \& CATHIA PAPI: The Open University has gone through a number of changes over the years. What have been the main milestones and what role have these played in the development of the institution?

MARTIN WELLER: During the 70s it established its model and reputation, including summer schools and relationship with the BBC, which broadcasted programmes linked to specific courses during the night.

In the 80s, funding was cut, which led to a rise in tuition fees and cuts to university services, but a government motion secured the OU following a petition of 165,000 signatures to 10 Downing Street - the seat of the government - organised by the OU Students Association. Throughout the decade, the government grant declined by over a quarter per undergraduate in real terms. This is when the university started exploring the use of computers also.

The 90s saw the arrival of the internet and, in 1999, our first large scale, fully online course, with 12,000 students.

The 00s saw the mainstream of e-learning, with all courses now having some online component and the university adopting Moodle as the VLE/LMS'. It also saw a change in how the term 'open education' was used, with interest in OER ${ }^{2}$. The OU responded with the founding of OpenLearn, our OER repository that has around 9M visitors annually (https://www.open.edu/openlearn/).

In more recent years, the UK has seen the introduction of student fees, which has had a detrimental effect on part-time study. This led to crisis with poor management, which came to a head in 2018 (https://blog.edtechie.net/ou/love-faith-hope-charity-the-future-of-the-ou/). Thankfully, we are now in more settled times and faring well.

In 2013, in response to the MOOC development the OU launched a separate company, FutureLearn, which has developed a platform providing MOOC largely from the British higher education sector.

Finally, in 2020, the OU has been supporting the sector as all providers seek to implement online learning. It has also seen a rise in OU student numbers as students choose to study with the OU over campus education.

\footnotetext{
${ }^{1}$ Virtual Learning Environment/Learning Management System

${ }^{2}$ Open Educational Resources
} 
HÉLÈNE PULKER \& CATHIA PAPI: Apart from being a distance education institution, what are the specificities of the Open University compared to traditional UK universities?

MARTIN WELLER: We are a national university, operating across four devolved governments (England, Wales, Scotland, and Northern Ireland), which have different funding arrangements from higher education and policies. Higher education is funded by student fees (except in Scotland) and not free for the learner and this impacts on part-time study more than full-time, because part-time students are often more cautious, and uncertain if they are ready for study, so committing to costly fees provides an additional barrier to entry. Furthermore, the $\mathrm{OU}$ is purely distance education and it is the largest higher education provider in the UK.

HÉLĖNE PULKER \& CATHIA PAPI: To what extent would you say the development and creation of distance learning materials have been transformed and influenced by the new technologies? How have technological advancements and distance teaching methodologies worked together over the years?

MARTIN WELLER: We have largely shifted from printed material to online delivery. Summer schools have largely been replaced by virtual laboratories and simulations, and face-to-face tutorials have largely been replaced by online ones. More and more content is placed on the VLE and the printing of materials such as books has reduced considerably. Students' learning, which was supported by video and audio tapes in the initial OU model of distance learning, and then by CDs and DVDs, is now supported via audiovisual materials and digital content downloadable from the VLE or via the OU Study App.

HÉLÈNE PULKER \& CATHIA PAPI: How would you describe a typical teaching job at the Open University? How has the teaching role evolved over the years?

MARTIN WELLER: The OU academic community is divided into two distinct groups. The first group consists of teams of lecturers, whom we call 'central academics', who develop the course materials and do not deliver tutorials. Over the years, their job has changed in the sense that they have had to shift from writing materials for printed books and audio and video tapes to writing materials for the VLE, using digital tools. They have had to rethink their pedagogy to make the most of the affordances of the technological tools, in order to design digital learning materials that were fit for purpose.

Then, students are supported by part-time tutors, who assist the understanding of the produced content, mark assignments, provide feedback and conduct tutorials. The tutors' role in distance education is very much that of a facilitator. Over the years, the tutors have had to adapt to the changing technology constantly. The first major change occurred when the OU started to produce online only courses and it was very challenging for most tutors to shift from teaching face-to-face and marking assignments on paper to teaching live tutorials online, facilitating and moderating online forums, and marking assignments electronically. As the technology advanced, tutors have had to adapt to new tools but most importantly, their role have become multi-faceted. Having to conduct tutorials in multi-modal teaching environments have called on tutors to acquire new skills.

Alongside their teaching duties, academics at the $\mathrm{OU}$ engage in pedagogic research and scholarship work aimed at improving the quality of teaching and learning, and the student experience. The institution also has a long-standing culture of pioneering innovative educational methods and technologies. The Institute of Educational Technology is a leading research centre in the field and publish an 'Innovative pedagogy report' every year which can be a useful reference for supporting educational practices in open and flexible education. 
HÉLĖNE PULKER \& CATHIA PAPI: Generally speaking, how would you describe your career at the Open University, what were your main achievements and what are the main changes at the Open University that have affected you positively or negatively?

MARTIN WELLER: I joined the OU in 1995 from my PhD, so it has pretty much shaped my entire career. I have learnt about the need to create carefully written materials, and to build in interaction. When I joined the OU, it matched with the internet years of the OU and open technologies, but I would say that my whole career path has been guided by how the meaning of 'open' has evolved at the OU over the years. I was first involved in an open source teaching project to apply open source software to teaching. It's the idea of the learning objects that was developing in the US with David Wiley, for example. Then I chaired the first OU large-scale online course, which attracted 12,000 students. Six hundred tutors were employed to teach the course online only. Going digital at scale was a real challenge, but with the support of the university, we developed the open VLE and used Moodle as our large e-learning platform.

The launch of OpenLearn took place in 2006. It is the largest repository of free content available online in the UK, and my involvement in this work marked the beginning of a clear path to supporting the university's mission of public engagement. At the same time, practising open education with web 2.0 and blogging helped me to develop an academic identity and a network. Through blog networking, I met George Siemens and started to work on MOOC (I was part of the advisory body for the FutureLearn platform), and Badged Open Courses, giving out free learning. The creation of the OER Hub and the global OER graduate network encouraged the adoption and promotion of open research practices including sharing data, methodology and ethics guidelines. In 2009, I started working with Open Access Publishing as an editor of the journal of interactive media in education, JIME, and published two books open access: The Digital Scholar in 2011 and The Battle for Open in 2014, both open licensed. I then did some work with open textbooks. I wanted to see if the US model could work in the UK. I found that unlike in the US, the cost of textbooks is not really the drive here, but there is a certain appetite for them nevertheless. More recently, I have been looking at how the nature of the relationship between students and knowledge has changed through the practices of open pedagogy. For example, we have created an open box course, allowing student to bring their informal learning through OpenLearn or MOOC, get formal credits and transfer to formal OU qualifications.

HÉLÈNE PULKER \& CATHIA PAPI: Open and flexible learning relies on learners' motivation and selfregulation. What would you advise teachers and students who are having to switch to remote education in the context of the pandemic?

MARTIN WELLER: I would advise teachers to use a learning design approach that helps build-in engagement. It is also important to support learners in developing their organisation and prepare them for being distance learners. For example, at the $\mathrm{OU}$, we have a short online course 'Being a distance learner'.

HÉLĖNE PULKER \& CATHIA PAPI: How do you see the role of the Open University in the light of an increase in distance and online learning? What is the raison d'être of the Open University in the current context? In other words, how do you see the future of the university?

MARTIN WELLER: I think the pandemic has made many people realise that the OU has been delivering high quality online content for a long time, and they want to learn how to do that. We have been working with the sector to share this expertise. On the longer term, the distance education model represents a more robust, more resilient system and the higher education sector needs to adapt elements of this (http://blog.edtechie.net/resilience/digital-resilience-in-the-time-of-pandemic/). 
If I was to give any advice to any incoming vice-chancellor, it would be to innovate around openness. If the OU innovates around what openness means in higher education, it will always stay current and relevant. It also helps to shape our identity and the identity of higher education. For society, open education is the future. 